\title{
Role of Entangled Stakeholders in the Development of Indonesia Digital Creative Ecosystem
}

\author{
Cici Cintyawati \\ Faculty of Economics and Business - Management, Universitas Islam Bandung (UNISBA) \\ cici.cintyawati94@gmail.com
}

\begin{abstract}
Digital creative industry in Indonesia growth rapidly in the last few years. This opportunity leads Indonesian central government declare a new vision to make Indonesia as the largest digital economy in ASEAN in 2020. To reach that vision, the first thing to do is build the digital creative ecosystem by integrating entangled stakeholders. By considering to this issue, this research was conducted to: (1) get deeper information about the digital creative ecosystem in Indonesia, (2) identify the roles of stakeholders in the digital creative ecosystem, and (3) analyze the role of stakeholders using service science perspective. Exploratory research was chosen to give better understanding related the types of issues happened in the ecosystem. Five key stakeholders were selected as informants so they can share their opinions and perspectives related to their role in the ecosystem. Strategic Options Development and Analysis then be used to analyze the transcribed interview. The result shows two major issues appeared in the digital creative ecosystem, which are collaboration and business ecosystem issues. It is found that there are four major roles in the digital creative industry: keystone, dominator, hub landlords, and niche player role. Association is expected to become the keystone to develop the ecosystem by sharing values with other stakeholders.
\end{abstract}

Keywords: Stakeholder's Role, Strategic Options Development and Analysis, Digital Creative Industry, Service Science

\begin{abstract}
ABSTRAK
Industri kreatif digital di Indonesia tumbuh pesat dalam beberapa tahun terakhir. Peluang ini membuat pemerintah pusat Indonesia mendeklarasikan visi baru untuk menjadikan Indonesia sebagai ekonomi digital terbesar di ASEAN pada tahun 2020. Untuk mencapai visi itu, hal pertama yang harus dilakukan adalah membangun ekosistem kreatif digital dengan mengintegrasikan para pemangku kepentingan yang terkait. Dengan mempertimbangkan masalah ini, penelitian ini dilakukan untuk: (1) mendapatkan informasi lebih dalam tentang ekosistem kreatif digital di Indonesia, (2) mengidentifikasi peran pemangku kepentingan dalam ekosistem kreatif digital, dan (3) menganalisis peran pemangku kepentingan menggunakan perspektif ilmu layanan. Penelitian eksplorasi dipilih untuk memberikan pemahaman yang lebih baik terkait jenis masalah yang terjadi di bidang yang diteliti. Lima pemangku kepentingan utama dipilih sebagai informan sehingga mereka dapat membagikan pendapat dan perspektif mereka terkait dengan peran mereka dalam ekosistem kreatif digital. Pengembangan Opsi Strategis dan Analisis kemudian digunakan untuk menganalisis wawancara yang ditranskripsi. Hasilnya menunjukkan dua masalah utama muncul dalam ekosistem kreatif digital, yaitu kolaborasi dan masalah ekosistem bisnis. Ditemukan bahwa ada empat peran utama dalam industri kreatif digital: keystone, dominator, tuan tanah hub, dan peran pemain khusus. Asosiasi diharapkan menjadi keystone untuk mengembangkan ekosistem kreatif digital dengan berbagi nilai dengan pemangku kepentingan lainnya.
\end{abstract}

Kata Kunci: Peran Stakeholder, Pengembangan Strategic Options dan Analisisnya, Industri Digital Creative, Service Science 


\section{INTRODUCTION}

\section{Background}

The evolution in the digital technology has eliminated the limit amongst producers and buyers (Towse \& Handke, 2013) and makes people can have an access to the new digital technology easily (Abbasi, 2017). A trend like the Internet of Things (IoT) that changed people's life has becoming a reality (Gregory, 2014) and successfully creates a new connected world that impact to the changes in the business industries (Abbasi et.al., 2017). This phenomenon then makes many countries around the world like Indonesia was trying to change that opportunity to bring a positive impact to the economy development in Indonesia, by creating an ecosystem for the development of digital creative industry (Das et al., 2016).

The development of digital creative industry in Indonesia has been showing an attractive growth. According to data released by Pricewaterhouse Coopers (PwC), a consulting firm, in 2010 the value of the Game Industry of \$ 56 Billion and the year increased to \$ 74 Billion. This value was just derived from the gaming industry, not including animation and other digital sub-sectors. With the increasing number of smartphone users in the world, the digital creative players' opportunities will be more widespread (Imran, 2015).

In response to this opportunity, a new way of thinking about business is needed. People need to shift their traditional thinking which views the company as part of single industry toward new thinking that views company as part of the business ecosystem (Moore, 1996). The business ecosystem is seen as one of the factors that determine business success and sustainability. Networks and interactions that form within the business ecosystem allow companies to interact and exchange resources to create new innovations (Kelly, 2015). Coevolvement from all stakeholders involved in the ecosystem then become a crucial issue in Indonesia since the current data shows that the ecosystem itself still not developed yet. Therefore, through this research, the author tries to reveal the role of each entangled stakeholders in the digital creative ecosystem so that they can collaborate each other to create a good ecosystem for the development of digital industry creative, especially in Bandung and Cimahi.

\section{Problem Identification}

Nowadays, the increasing number of stakeholders who participated in the digital creative ecosystem (Noor, 2015) like academia, government, business players (Noor, 2015), incubators, and community (Ryza, 2015) become a good movement in achieving Indonesian vision to be the largest digital economy in ASEAN by 2020. By focusing in developing the ecosystem, it is expected can makes the collaboration among stakeholders can be optimum and enhance the interaction between the stakeholders and broader economy.

This situation then makes researches about the digital creative industry become important. But, unfortunately, the research discussed about the digital creative industry is still limited, especially papers that discussed about the digital creative industry as ecosystem. Many researchers just focus on the creative industry itself, not focus on the digital creative industry like many studies in the creative industry just related to service innovation (Aal, et al., 2016; Perks et al., 2012) and many other, but there is a limited study on the digital creative industry. 
To fulfill the gaps between the Indonesian vision to become the largest digital economy in ASEAN (Southeast Asia) by 2020 and the lack of studies about the digital creative ecosystem, an explanatory research would be conducted to analyze the role of stakeholders in the digital creative industry. Service science concept then will be used as a major concept in analyzing the interaction among stakeholders in co-creating value in the ecosystem (Vargo et al, 2010).

\section{Problem Formulation}

Based on the background and problem identification above, the author addressed these three research questions as below. (1) What kind of issues faced by the stakeholders in the digital creative ecosystem? (2) How are the digital creative stakeholders' roles in the digital creative ecosystem? (3) How are the digital creative stakeholders' roles in business ecosystem by relating to the service science concept?

\section{THEORETICAL BASIS}

\section{Keystone Strategy in the Business Ecosystem}

Iansiti and Levien $(2004 b$; 2005) proposed four major roles of players inhabit in the business ecosystem which are keystones, dominators, hub landlords, and niche players. To give better illustration about the idealized business ecosystem, figure below will figure out the differences among those four players.

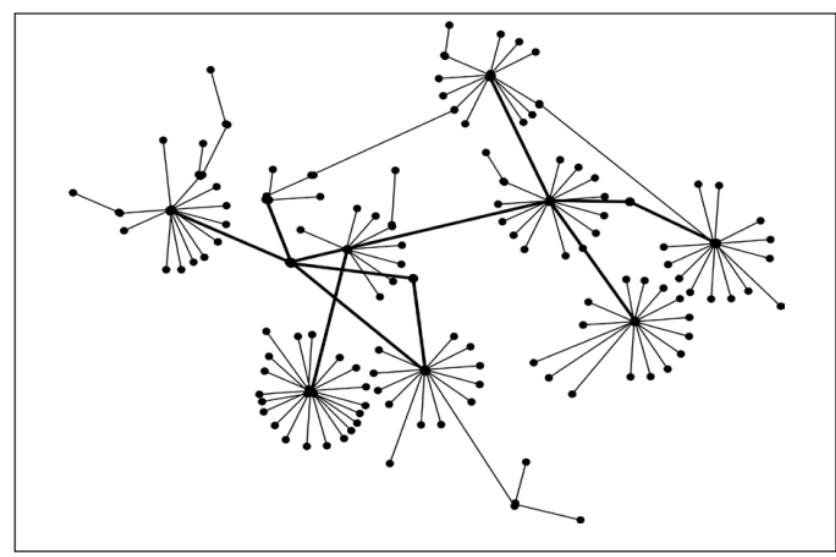

Figure 1. Illustration of Business Ecosystem

Source: Iansiti and Levien, 2004a

Based on the figure 1, the thick lines and large nodes represent keystone in the business ecosystem. In that figure, although keystones occupy a small portion of the total nodes in the network of ecosystem, but their role is crucial in the ecosystem (Iansiti and Levien, 2004; Karhiniemi, 2009). Karhiniemi (2009) argues that keystone company actively enhances the health of business ecosystem. Keystone company role in the ecosystem can foster and improve the ecosystem health (Iansiti and Levien, 2004; Karhiniemi, 2009). Keystone role in the company is perceived is crucial to create and share value with their network since their position is in the network is as central hub (Karhiniemi, 2009). 
Besides of keystone, the second important role in the ecosystem is dominators. Iansiti and Levien (2004) argued that dominators put their effort to win the market share (Iansiti and Levien, 2004) and have large control in the network and integrate a large part of the network both vertically or horizontally (Karhiniemi, 2009). The differences between dominators and keystone are lies on the size and their possibility to taking over other species functions in the ecosystem. In term of size, dominators are bigger than keystone.

The third role is hub landlords. Different with keystone and dominators, hub landlords have small portion in value creation and have low presence in the ecosystem. But they will absorb as many as value from the ecosystem without having direct control to the ecosystem.

The last role in the ecosystem is niche players. When niche players are seen individually, they did not have huge power in the ecosystem since they can't have broad impacts for other species (Karhiniemi, 2009). But, if they are seen collectively, they have powerful impacts in the ecosystem (Iansiti and Levien, 2004) in terms of population number and variety. Each of them may have different skills and expertise so they have capabilities to create innovation in the ecosystem (Karhiniemi, 2009).

\section{Digital Creative Ecosystem}

Digital creative industry is industry that use digital IT, creativity, and other intellectual resources to create digital products (AIMIA, 2005, Sneha, 2016; Leung and Bentley, 2017). There are several types of digital products which are: games, music, animation, software, elearning, apps/website-based tourism, e-commerce, etc. (AIMIA, 2015; Leung and Bentley, 2017). Meanwhile, in Indonesia, Creative Economy Agency (BEKRAF) has mentioned about several digital products in Indonesia. Those products are Games, Education, Music, Animation, Software and Social Media (GEMASS). Companies whose produce and sell such kinds of products then is called as digital creative companies.

\section{Service Science Perspective}

Service science is a study used to learn about service systems and as an abstraction from service systems. It uses service as philosophical foundation. The concept of service science was first introduced by the Council' s co-chairman and president of IBM, Samuel Palmisano. He mentioned about the importance of service science as the foundation to innovate service to enhance the growth of economy.

Abe (2005) give explanation about the service science as a media where providers and customers can collaborate each other and share their resources and risk to reach each other goals. Meanwhile, Vargo and Lusch (2008) defined service science as a study which focuses on the interaction of entities to co-create value in the service system. Form several definitions about service science above, it can be concluded that service science is an interdisciplinary study that focuses on the service systems and interaction among entities involved in co-creating value to enhance productivity, quality, operational innovation and development in service.

\section{Strategic Options Development and Analysis with Cognitive Mapping}

To reach the purpose of this research, the important step is analyzing the role of each stakeholder using Strategic Option Development and Analysis (SODA). SODA is a method 
that helps to fix a complex problem by building consensus options from different elements (Ackermann and Eden, 2001). By using this method, the researcher tries to solve complex issues in the ecosystem. Through this method, opinion and insights from each stakeholder will be obtained and will be constructed using cognitive mapping to illustrate the causality of the problems. The cognitive maps will be analyzed to get some insight related issues faced and appropriate solution to overcome those issues (Ackermann and Eden, 2001).

In SODA, cognitive mapping is used to help the researcher to analyze and present the result of SODA (Eden and Ackermann, 2001). Cognitive map according to Ackermann and Eden (2004) used perspective and interpretivism view of individual or organization to describe the problems so the model can be developed. Semi-structured interview then be conducted to gather some information from the informant related to the issues faced. The cognitive map then will be built after make interview transcript and coding the transcript. The process of creating and validating the cognitive map is an iterative process to make sure the cognitive maps are appropriate and can described the real situation (Ackermann and Eden, 2001). Eden (1988) argues that cognitive mapping is more appropriate and has practical significance in mapping the problems.

\section{RESEARCH METHOD}

\section{Research Design}

Qualitative approach is used to dig deeper into the subject and find new issues that have not been identified before. Semi-structure interviews then were conducted to give deeper information from the participants since through this technique, the participants can say everything that comes in their mind relating to the interview topic (Carpenter and Lertpratchya, 2016, p. 452), along with the objectives of this exploratory research. In addition, focus group discussion will be used to get more issues and collect alternative solutions to solve the issues.

\section{Site Selection}

Bandung as one of the big cities in Indonesia become the first site selection since this city was famous with its digital creative products. Meanwhile, Cimahi was chosen as the site in this research because this city is famous with its digital products like animation, games, and other telematics products. Many people even called Cimahi as animation city since an annual international animation festival was held there. The government of this city then focused on their goal to make Cimahi as innovative hubs where innovation, creativity as well as entrepreneurship initiate the journey there. The government of this city have some programs to improve the citizen's life and foster the economic development through the creative cities; one of the future identities includes a reputation for digital creative.

\section{Data Collection}

In collecting data, depth interview using semi-structured interview, literature review, and focus group discussion were become the source of data of this research. One-on-one interviews were conducted to give more exploration about the real condition of the subject (Robson, 2002) and to get the best thinking of each interviewee (Palmerino, 2009). The interviews were conducted with five (5) key interviewees which are incubator manager in Institute for Innovation and Entrepreneurship Development ITB (LPIK ITB), Indonesian 
government, the chairman of Cimahi Creative Association (CCA), business (Ayena Studio), and academia (lecturer in a university in Bandung). Below is detail information about the informants of this research.

\section{Data Analysis}

The data obtained from one-on-one interview and FGD then will be interpreted and analyzed using Strategic Options Development Analysis (SODA) and Atlas. Through SODA, the researcher will build cognitive map for each stakeholder. Meanwhile, by using Atlas, the researcher can capture the most important issues appear in the digital creative industry.

\section{DISCUSSION}

\section{Current Issues in the Ecosystem}

Since the first question of this research is to know the issues happened in the digital creative industry in Indonesia, the exploration was started by interviewed five key informants. Those interviewees are expected to give their perspective related digital creative industry in Indonesia. To build individual cognitive maps, the interview results were transcribed and code and then be analyzed using SODA method. Table below explain the issues derived from the fifth informants of this research.

Tabel 1 Matrix of Individual Cognitive Maps

\begin{tabular}{|c|c|c|c|c|c|}
\hline \multirow{2}{*}{ Issues } & \multicolumn{5}{|c|}{ Stakeholders } \\
\cline { 2 - 6 } & Government & Association & Business & Academia & Incubator \\
\hline $\begin{array}{c}\text { Business } \\
\text { ecosystem }\end{array}$ & $\sqrt{ }$ & $\sqrt{ }$ & $\sqrt{ }$ & $\sqrt{ }$ & $\sqrt{ }$ \\
\hline Collaboration & $\sqrt{ }$ & $\sqrt{ }$ & $\sqrt{ }$ & $\sqrt{ }$ & $\sqrt{ }$ \\
\hline $\begin{array}{c}\text { Business } \\
\text { objectives }\end{array}$ & - & $\sqrt{ }$ & $\sqrt{ }$ & - & - \\
\hline Academia & $\sqrt{ }$ & $\sqrt{ }$ & - & $\sqrt{ }$ & $\sqrt{ }$ \\
\hline
\end{tabular}

Source: Data Processing Result

Based on the interview result, there are four issues appeared in the digital creative industry, like government involvement, academia, collaboration, business ecosystem, and business objective. From those issues, there are two issues are raised from all of informants. Those issues are collaboration and business ecosystem issue. Academia issues are raised from academia, government, and incubator since they are very concern in developing the start-ups' skills and capability. Then, business objective is just raised from association and business. It is natural since business has its own objective, especially to generate profit to enhance their business. Meanwhile association, although they are not too concern for profitability but most of the members are business player who has their own business objective.

After identifying the major issues faced by all of informants, the next step is to create a merged cognitive map. Here is the merged cognitive maps. 


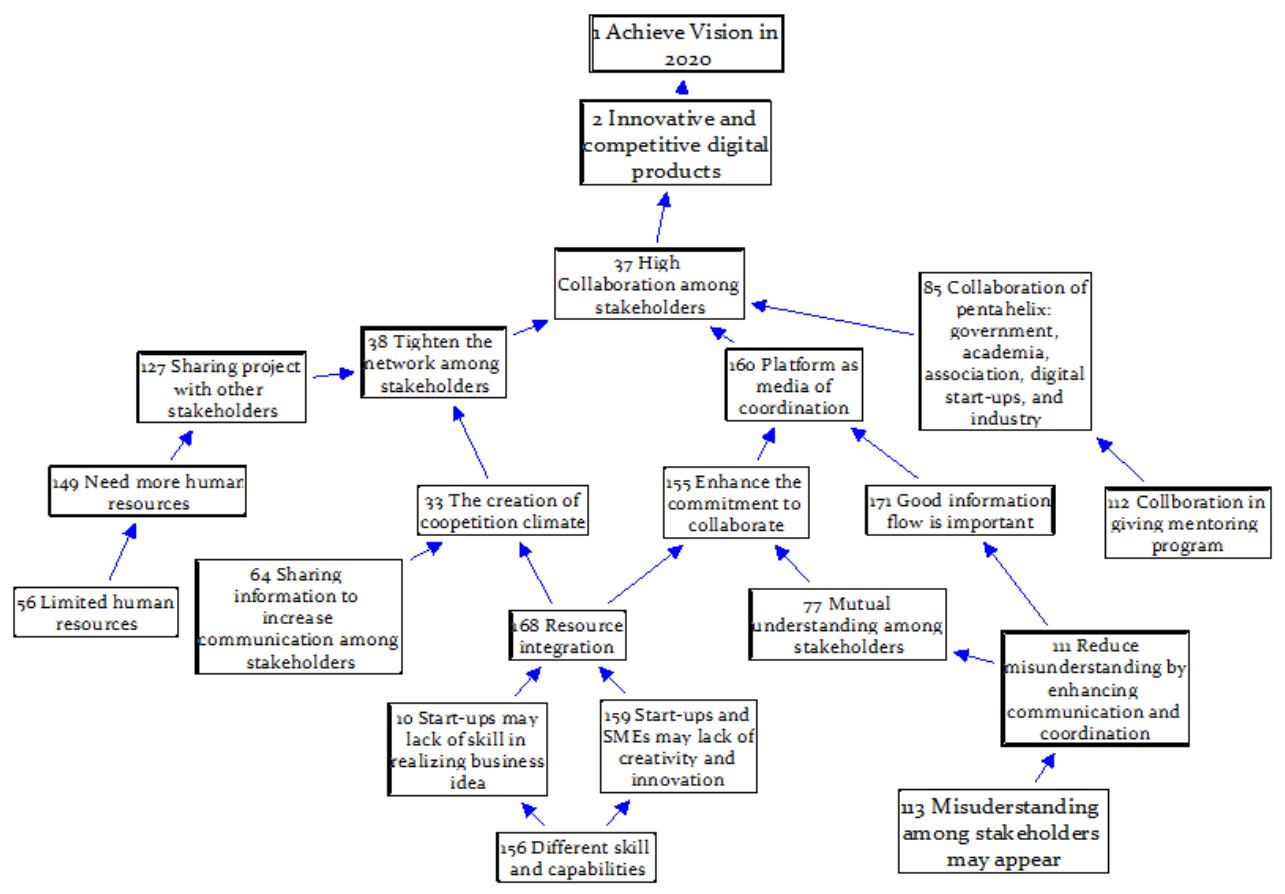

Figure 2. Merged Cognitive Map for Collaboration Issue (Source: Data Processing Result)

In the figure above, each box describes the perspective from each informant. Based on the merge cognitive map above, high collaboration among stakeholders is needed to achieve the Indonesian vision in 2020. To increase the collaboration issues, each stakeholder needs to tighten their network through some activities like sharing projects. By sharing the project with other parties or even competitor, stakeholders can create collaborative or coopetition environment so it may reduce the gaps among stakeholders and integrate the resources they have.

Currently, to create a collaboration and communication among digital creative companies, they are using digital platform as a media to share information and projects with other companies in many cities in Indonesia. Such platform gives positive impact for them so they can co-evolve. They can share the projects when their work is overload. They did not need to worry that their project since each company has their own capability and capability to finish the project. They are not worry about their competitors. They think that collaboration and competition can be done without having to defeat each other. Competition as well as collaboration (coopetition) becomes strength for them to keep running their business. There is no loser or winner. All digital creative companies can help each other to become success and co-evolve without make other companies lose their chance to develop their business.

Such kind of thinking should be applied by all of stakeholders to develop an ideal ecosystem. All stakeholders should open their mind to collaborate with other stakeholders. They need to reduce their egos so mutual understanding among them can be created. Low collaboration faced today may be caused by each stakeholder too concerned about their objectives without see the potential of collaboration. It also may cause by the absence of platform to bridge the collaboration among them, so they sometimes confused to start the 
collaboration. So, the initiator and platform are needed to help them collaborate each other in the ecosystem.

Besides of collaboration issue, another issue derived is about business ecosystem issue. Here is the merged cognitive map for business ecosystem issue.

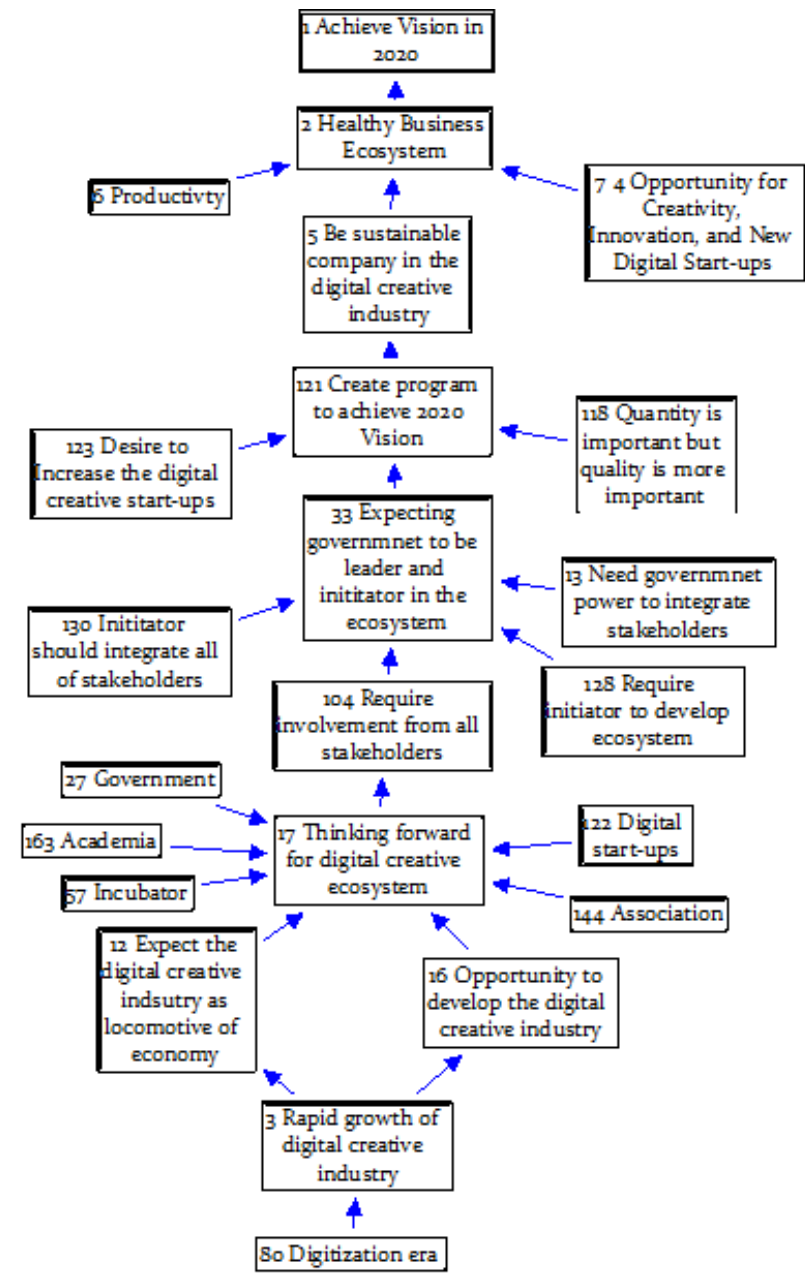

Figure 3. Merged Cognitive Map for Business Ecosystem Issue (Source: Data Processing Result)

Based on the the cognitive maps above, there are several characteristcs of business ecosystem derived from key informants. Those characteristics are: (1) ecosystem leader, (2) networking, (3) platfrom, and (4) healthy business ecosystem. Those characteristics were supported by the previous research conducted by several researchers like Iansiti and Levien (2004), Kelly (2015), Raivio et al. (2011).

\section{Types of Entangled Stakeholders in the Digital Creative Industry}

The interview result shows that the digital creative industry consist of several types of stakeholders like Business (Digital Creative Companies), academia (universities, researchers, etc.), government, association/community, incubator, customers, producers (animators, game producers, music producers, movie makers, etc.), public service advertiser, and customer. From 
the interview result, the researcher tries to describe just five stakeholders whose inhabit the ecosystem of digital creative industry. It is because, all of informants highlight about those five stakeholders. Meanwhile, other four stakeholders like customer, public service advertiser, investor, and animation producers will not be discussed deeply in this research since the informants were not too concern about those four stakeholders.

\section{Roles in Digital Creative Ecosystem}

In terms of digital creative ecosystem, key informants perceived that association can become a keystone in the ecosystem since they have some programs and events as platform to share value and benefits to other stakeholders. In this case, CCA has potential to become the keystone in the ecosystem since they help the development of business not only in Cimahi, but also in other cities. They also have good networking system with other stakeholders. They can be government partner in realizing the vision in 2020. Since government's role is expected as dominator, so they can provide facilities and create some regulation to support the keystone. But, currently, the key informants argue that government involvement is quite low. So, it is important to increase the government involvement in the ecosystem.

In addition, big companies may have role as hub landlords. They have high potential, but their involvement in the ecosystem is lower than niche players. The last role is niche players. SMEs and digital start-ups are perceived have role as niche players in the ecosystem. Their power may be small if they act individually, but if they act collectively their power is getting bigger so it can support the achievement of vision in 2020. To reach that vision, the digital creative entrepreneurs are the main Indonesian government focus. It is because they are perceived can increase the creativity and innovation in the ecosystem so it can be competitive advantages for Indonesia to compete with other countries.

“...it is important to increase start-ups' creativity and innovation since it can be competitive advantages for them." (ASS027)

The interview results also revealed that the involvement of each stakeholder is very diverse. For example, the association said that government involvement in the ecosystem is still in the medium level, whereas their potential is very high to develop the ecosystem since their role is dominator in the ecosystem. In addition, the involvement of business and it is still in the medium level. This result was derived from the interview result with government and association. They said that business has high potential to create innovation and creativity in the ecosystem, but currently their role is still not optimum caused by some of them may think that they did not need other parties' intervention in managing their business.

"We can create our product by ourselves. Other parties are sometimes too slow in following the rapid changes in the digital creative industry" (DSP012)

The interview result shows that lack of trust may cause the involvement of stakeholders in the ecosystem still in the medium level. Then, the interview result with the government also shows that the involvement of association in the ecosystem still not optimum, whereas the potential is high. The government said that currently, the association just organizes some annual events. To increase their involvement, the association needs to create more creative and innovative events to help the digital creative companies in promoting their product. The 
government also said that they are enthusiast to help the association by giving some facilities and funds to hold the events.

Other opinion related the stakeholders' involvement also derived from academia, association and business. They said that the involvement of producer (animator, music producers), investor and public service advertiser are still low. Academia said that the number of investor for digital creative product is still limited. Some of them are difficult to be found since they prefer to give their funds for big companies whose have sustainable business. Those opinion was supported by the business (in this case is small companies) that said they are difficult to get investor who are willing to fund their products. Then, association also talked about the involvement of public service advertiser. The association said that public service advertiser has high potential to help the business in promoting their products, but in Indonesia, the role of public service advertiser is still low so many digital creative companies, especially start-ups and SMEs are difficult in promoting and marketing their products.

\section{Roles of Stakeholders from Service Science (SD-Logic) Perspective}

Digital creative industry consists of four major roles, which are keystone, dominator, hub landlords, and niche. Since each stakeholder share the same vision to make Indonesia as the largest digital economy in 2020, they should collaborate each other to increase the value creation in the ecosystem. This concept is like the concept of value co-creation in the service science. In addition, association as keystone in the digital creative industry provide platform, this concept also is similar with the concept of value orchestrator in the S-D logic and value orchestration platform. Then, according to S-D logic concept, that platform also can be used as media to attract customer to the ecosystem and collect their thoughts and perspective to enhance the development of digital creative ecosystem.

Association which is CCA has creates a platform to gather many stakeholders in one place. That platform is in the form of annual events like Baros International Animation Festival (BIAF) and Bandung International Digital Arts Festival (BIDAF) as beneficial events for other stakeholder to share value and integrate their resources. In 2016, BIAF has successfully invited participants and speakers from 11 countries. BIAF can be a platform to gather the stakeholders in the digital creative industry, such as animation studio, game development, comic artists, illustrators, media, agencies, software developers, merchandising, IT industry developers, communities/association, government, and animation lovers (customers). BIAF is used as media of communication of animators and creative people from various countries to realize the collaboration and improve the quality of animation as well as build a global animation network (networking) and open a global market for animators in Indonesia. BIAF also can be a media to promote the digital products and to find investors.

Besides of BIAF, another annual event is BIDAF. BIDAF is annual event to promote some digital creative products like video artwork, animation, digital games, digital imaging, sonic art, robotic arts, interactive installations, etc. The festival has gathered more than 50 Indonesian and international artists in the digital creative industry. BIDAF also become a media to gather stakeholders in the digital creative industry such as governments, artists in the digital creative industry, academia, communities, and other stakeholders. This event became a media to increase collaboration and improve the quality of digital creative products as well as build a global digital creative network (networking) and open a great opportunity for the international digital creative market. 
After reviewing the BIAF and BIDAF events from year to year, although both events are successful, but the impact for the digital creative industry is still not optimum since there are many companies in the creative industry that are still difficult in promoting and developing their business. Since this event is held only once a year so the effect is still not optimal. In addition, although both events can gather various stakeholders in the digital creative industry, but collaboration among stakeholders is still not optimal. In addition, there is still misunderstanding between stakeholders. For example, currently, there is a misunderstanding between community and local government caused by government regulation regarding technopark facilities. Whereas, those two stakeholders are the organizer for the BIAF so it means that annual event may not an appropriate platform to enhance the collaboration and coordination among stakeholders.

\section{CONCLUSION}

\section{Conclusions}

Digital creative ecosystem in Indonesia has not created properly. To create the ecosystem, the involvement of each stakeholder through make some collaboration with other stakeholders. It is because, the result shows that collaboration activity is quite low to medium. There are some issues faced by the stakeholders in the ecosystem, such as issue about collaboration and business ecosystem. In relating to the collaboration issues, platform is needed to increase the collaboration among stakeholders.

There are four major roles in the digital ecosystem, which are keystone, dominator, hub landlords, and niche. Association has a role as the keystone, government as the dominator, producers as the hub landlords, meanwhile other stakeholders have role as niche players. By using service science perspective, the researcher perceives that keystone role in the ecosystem is quite similar with the role of platform orchestration in the service science concept, especially in the concept of value orchestration platform. Keystone role as platform orchestrator provide platform to deliver the value to other customers so each stakeholder can get benefits. In this research, digital (virtual) platform is expected will be more appropriate to be used by the stakeholders than real platform since this platform can be used anytime, anywhere, and by anyone. Then, by using service science concept, the researcher involves the customer as one of the value creators by since they have contribution to the products creation by giving their feedback or insight related the products. They also may promote the products to other customer so they are involved as value co-creator in the digital creative industry.

\section{Recommendations}

This research has some limitations, especially related to the scope, time, and method used. This research limits the topic just on one topic which is business ecosystem and also limits the number of informant becomes five informants, which are academia, government, association, incubator, and business. Whereas, the result shows that there are other stakeholders involved in the ecosystem. So, for the next research, the researcher needs to enlarge the scope and also increase the number of informant. Then, since there are three issues arose in the ecosystem: collaboration, government involvement, and business ecosystem, for the next research, the researcher can focus to dig deeper on those three issues. In addition, this research just used SODA and Atlas to analyze the result. For the future research, the researcher can add 
other methods like system dynamics, agent-based modeling or even other soft system method to get deeper understanding about the digital creative industry.

\section{REFERENCES}

Aal, K, Pietro, L.D., Edvardsson, B., Renzi, M.F., Mugion, R.G. (2016). Innovation in service ecosystems: An empirical study of the integration of values, brands, service systems and experience rooms. Journal of Service Management, Vol. 27 Issue: 4, pp.619-651

Abbasi, M., Vassilopoulou, P., and Stergioulas, L. (2017). Technology Roadmap for the Creative Industries. Creative Industries Journal, Vol. 10, No. 1, 40-58.

Abe, Tadahiko. (2005). What is Service Science? Research Report, No. 246. Tokyo: Fujitsu Research.

Ackerman, F., and Eden, C. (2001). Contrasting single user and networked group decision support systems for strategy making. Group Decision and Negotiation, 10(1), 47-66.

Australian Interactive Media Industry Association (AIMIA). (2005). Digital Content Industry Roadmapping Study. Australia.

Carpenter, S., and Lertpratchya, A.P. (2016). A Qualitative and Quantitative Study of Social Media Communicators: An Extension of Role Theory to Digital Media Workers. Journal of Broadcasting \& Electronic Media, 60 (3), 448-464.

ConferenceSystem Sciences (HICSS), 44th Hawaii International Conference.Ryza, Prayogo. (2015). Menggantungkan Harapan Industri Kreatif. https://dailysocial.id/ post/hut-ri-70tahun-industri-kreatif.

Das, K., Gryseels, M., Sudhir, P., and Tan, K.T. (2016). Unlocking Indonesia's Digital Opportunity. McKinsey \& Company Indonesia Report.

Eden, D. (1988). Pygmalion, goal setting, and expectancy: Compatible ways to raise productivity. Academy of Management Review, 13, 639-652.

Eden, C., and Ackermann, F. (1998). Making Strategy: The Journey of Strategic Management. Sage, London.

Gregory, J. (2014). The Internet of Things: Revolutionizing the Retail Industry. Accenture Strategy. Available in: https://www.accenture.com/_acnmedia/ Accenture/ConversionAssets/DotCom/Documents/Global/PDF/Dualpub_14/ Accenture-The-Internet-OfThings.pdf 
Iansiti, M., and Levien, R. (2004). Strategy as Ecology. Harvard Business Review, pp.68-78.

Iansiti, M., and Levien, R. (2004b). The Keystone Advantage: What the New Dynamics of Business Ecosystems Mean for Strategy, Innovation and Sustainability. Harvard Business School Press, Cambridge.

Imran, Muhammad. (2015). Membangun Industri Kreatif Digital Indonesia. https://www.linkedin.com/pulse/membangun-industri-kreatif-digital-indonesiamuhammad-imran/.

Karhiniemi, M. (2009). Creating and sustaining successful business ecosystems. Master's thesis, Helsinki School of Economics (HSE).

Kelly, Eamonn. (2015). Introduction: Business Ecosystems Come of Age. Deloitte Insight, April 2015. https://www2.deloitte.com/insights/us/en/focus/ businesstrends/2015/business-ecosystems-come-of-age-business-trends.html

Leung, L., and Bentley, N. (2017). Producing Leisured Laborers: Developing Higher Education Courses for the Digital Creative Industries. The Journal of Arts Management, Law, and Society, Vol. 47, Issue 2.

Moore, James F. (1996). The death of competition: leadership and strategy in the age of business ecosystems. Wiley \& Sons: Chichester.

Noor, Achmad Rouzni. (2015). Anak Muda, Masa Depan Kreatif Digital. https://inet.detik.com/cyberlife/d-2923049/anak-muda-masa-depan-kreatif-digital.

Perks, H., Gruber, T. and Edvardsson, B. (2012), Co-creation in Radical Service Innovation: A Systematic Analysis of Microlevel Processes. Journal Product Innovation Management, 29: 935-951. doi:10.1111/j.1540-5885.2012.00971.x

Raivio, Y., Luukkainen, S., Seppala, S. (2011). Towards Open Telco - Business Models of API Management Providers. IEEE Xplore

Sneha, P.P. (2016). Studying Digital Creative Industries in India: Initial Questions. Centre for Internet \& Society. http://cis-india.org/raw/studying-digital-creative-industries-in-indiainitial-questions.

Towse, R., and Handke, C. (2013). Handbook on the Digital Creative Economy. Cheltenham UK and Northampton MA USA, Edward Elgar Publishing.

Vargo, S.L., and Lusch, R.F. (2008). Service-Dominant Logic: Continuing the Evolution. Journal of the Academy of Marketing Science 36 pg. 1-10.

Vargo, S. L., R. F. Lusch. M. A. Akaka. (2010). Advancing Service Science with Service Dominant Logic Clarifications and Conceptual Development. 